\title{
Pengaruh Profitabilitas dan Ukuran Perusahaan Terhadap Penghindaran Pajak pada Perusahaan Manufaktur Sub Sektor Otomotif yang Terdaftar di Bursa Efek Indonesia
}

\author{
Eko Cahyo Mayndarto \\ Accounting Departement, Economy Faculty,Tama Jagakarsa Univiversity \\ ekocmayndarto@gmail.com
}

*Penulis Korespondensi

$\begin{array}{ll}\text { Diajukan } & : 12 \text { Desember } 2021 \\ \text { Disetujui } & : 26 \text { Desember } 2021 \\ \text { Dipublikasi } & : 1 \text { Januari } 2021\end{array}$

ABSTRACT

Taxes are a very large source of state revenue which is used to finance government expenditures, such as financing government administration, building infrastructure, providing education and health facilities. Taxes are said to be mandatory because they are already stated in the law and there are even regulations governing taxation. Every taxpayer is required to take part so that the growth and implementation of national development can run well. The type of research used is descriptive quantitative analysis method. This study uses secondary data obtained from the documentation. Quantitative descriptive analysis is done by collecting and classifying according to certain criteria or patterns, the data that has been quantified and the analysis is used to get a systematic picture of the contents of a document. Sources of data used in this study is secondary data sources, namely data obtained from existing documents. So that data in finished form has been collected and then processed by other parties and is usually in the form of publications. The secondary data used is in the form of the annual report of companies listed on the IDX in 2015-2019 related to research variables. The data in this study comes from the Indonesia Stock Exchange website and the company's website. The results of the research and discussion can be concluded. There is a partial negative and significant effect between the profitability variable (ROA) on tax avoidance in manufacturing companies in the automotive sub-sector. There is a positive and partially significant effect between company size variables on tax avoidance in manufacturing companies in the automotive sub-sector. There is a simultaneous significant effect between profitability (ROA) and firm size on tax avoidance in manufacturing companies in the automotive sub-sector.

Keywords: Profitability, Company Size, Tax evasion

\section{Catatan : Tambahkan ABSTRAK in Bahasa}

\section{PENDAHULUAN}

Pajak adalah salah satu sumber pendapatan negara yang sangat besar yang digunakan untuk membiayai pengeluaran pemerintah, seperti membiayai administrasi pemerintah, membangun infrastruktur, menyediakan fasilitas pendidikan dan kesehatan. Pajak dikatakan wajib karena sudah tercantum dalam undang-undang bahkan sudah ada 
peraturan yang mengatur tentang perpajakan, Setiap wajib pajak diharuskan untuk turut serta andil agar pertumbuhan dan pelaksanaan pembangunan nasional dapat berjalan dengan baik. (Dewinta dan Setiawan, 2016)

Pajak adalah sumber pendapatan utama suatu negara untuk pembangunan dan kesejahteraan warga negara yang memikat, terutama di Indonesia. Berdasarkan UndangUndang KUP Nomor 28 Tahun 2007 Pasal 1 ayat 1, pajak merupakan kontribusi wajib kepada negara yang dimiliki oleh individu atau badan yang dipaksa berdasarkan UU, dengan tidak mendapatkan kompensasi secara langsung dan digunakan untuk kebutuhan negara untuk kemakmuran terbesar rakyat. Pajak dapat dikatakan sebagai sesuatu yang tidak menguntungkan dan membebani wajib pajak karena dapat mengurangi kemampuan daya beli warga negara.

Institusi membuat kepentingan mereka berbeda. Sebagai contoh adalah pemerintah dan perusahaan. Pemerintah harus meningkatkan jumlah pendapatan negara dengan penerimaan pajak karena pajak dianggap sangat potensial dalam mempengaruhi dan meningkatkan pendapatan negara, yang digunakan untuk membiayai semua kegiatan pemerintah.

Seperti halnya perusahaan yang berbanding terbalik dengan pemerintah, perusahaan akan merasa sangat terbebani dengan kenaikan biaya produksi, karena dengan meningkatnya biaya produksi seperti biaya bahan baku akan menambah jumlah pajak yang harus dibayar oleh perusahaan secara langsung. Kepentingan yang berbeda antara perusahaan dan pemerintah menyebabkan perlawanan pajak. Resistansi pajak dibagi menjadi dua, yaitu perlawanan pasif dan perlawanan aktif. Perlawanan pasif adalah hambatan yang dapat menyulitkan kegiatan pengumpulan pajak dan memiliki hubungan yang erat dengan ekonomi, sementara resistensi aktif adalah berbagai usaha dan tindakan yang diarahkan pada pemerintah (otoritas pajak) dengan tujuan untuk menghindari pajak. Perusahaan dapat melakukan perencanaan pajak untuk meminimalkan pembayaran pajak. Perencanaan pajak adalah strategi yang digunakan untuk mengelola keuangan perusahaan untuk meminimalkan hal-hal yang berkaitan dengan pembayaran pajak dan tidak melanggar undang-undang perpajakan atau secara hukum.

Ada dua strategi perencanaan pajak yang umum digunakan, yaitu penghematan pajak dan penghindaran pajak. Penghematan pajak adalah upaya untuk merampingkan beban pajak dengan memilih pajak dengan tarif yang lebih rendah. Strategi lain yang dianggap lebih efektif adalah penghindaran pajak. Penghindaran pajak adalah metode atau strategi yang digunakan untuk meminimalkan pembayaran pajak tanpa harus melanggar undang-undang dan peraturan perpajakan. Dalam penelitian ini, penghindaran pajak diukur dengan menggunakan tarif pajak efektif tunai (CETR). CETR digunakan dengan baik untuk menggambarkan kegiatan penghindaran pajak karena tidak terpengaruh oleh perubahan estimasi seperti penilaian atau perlindungan pajak. Semakin tinggi tingkat persentase CETR yang dekat dengan tarif pajak penghasilan perusahaan sebesar $25 \%$ menunjukkan bahwa semakin rendah tingkat penghindaran pajak perusahaan, sebaliknya semakin rendah tingkat CETR menunjukkan bahwa tingkat penghindaran pajak lebih tinggi (Dewinta dan Setiawan, 2016: 1587).

Pengaruh pajak sebagai penerimaan terbesar pendapatan negara dapat dilihat dari realisasi penerimaan negara pada tabel 1 sebagai berikut: 
Tabel 1

Realisasi Penerimaan Negara Tahun 2015-2019 (Dalam Miliar Rupiah)

\begin{tabular}{ccrrrr}
\hline Tahun & $\begin{array}{c}\text { Penerimaan } \\
\text { Pajak }\end{array}$ & $\begin{array}{c}\text { Penerimaan } \\
\text { Bukan Pajak }\end{array}$ & Hibah & Total & $\begin{array}{c}\text { \% } \\
\text { Pajak }\end{array}$ \\
\hline 2015 & $1.240 .418,86$ & $255.628,48$ & $5.034,50$ & $1.508 .020,37$ & $82,25 \%$ \\
2016 & $1.284 .970,10$ & $261.976,30$ & $8.987,70$ & $1.555 .934,20$ & $82,59 \%$ \\
2017 & $1.343 .529,80$ & $311.216,30$ & $11.629,80$ & $1.666 .375,90$ & $80,63 \%$ \\
2018 & $1.518 .789,80$ & $409.320,20$ & $15.564,90$ & $1.943 .674,90$ & $78,14 \%$ \\
2019 & $1.546 .141,90$ & $408.994,30$ & $5.497,30$ & $1.960 .633,60$ & $78,86 \%$ \\
\hline
\end{tabular}

Sumber: www.bps.go.id diolah (2021)

Penerimaan pajak saat ini terus mengalami peningkatan, berdasarkan informasi Badan Pusat Statistik (BPS), terlihat bahwa penerimaan pajak di Indonesia pada tahun 2015 (dalam miliar rupiah) mencapai Rp 1.240.418,86 dan terus mengalami peningkatan hingga tahun 2019 yang mencapai $\mathrm{Rp}$ 1.546.141,90. Meskipun dalam realisasinya pajak mengalami peningkatan. Akan tetapi hal tersebut tidak dapat menutup kemungkinan bahwa penerimaan pajak di Indonesia tidak mencapai target APBN. Target APBN sebesar Rp1.743,6 triliun," kata Menkeu Sri Mulyani, dalam konferensi persnya seusai menghadiri rapat kabinet tentang pemulihan ekonomi di Istana Kepresidenan. Salah satu penyebabnya yaitu kesadaran wajib pajak yang masih kurang terhadap kewajiban untuk membayar pajak. Target pendapatan negara dari penerimaan pajak dapat dilihat pada diagram 1 sebagai berikut:

\section{Diagram 1}

Target Penerimaan Pajak Tahun 2015-2019

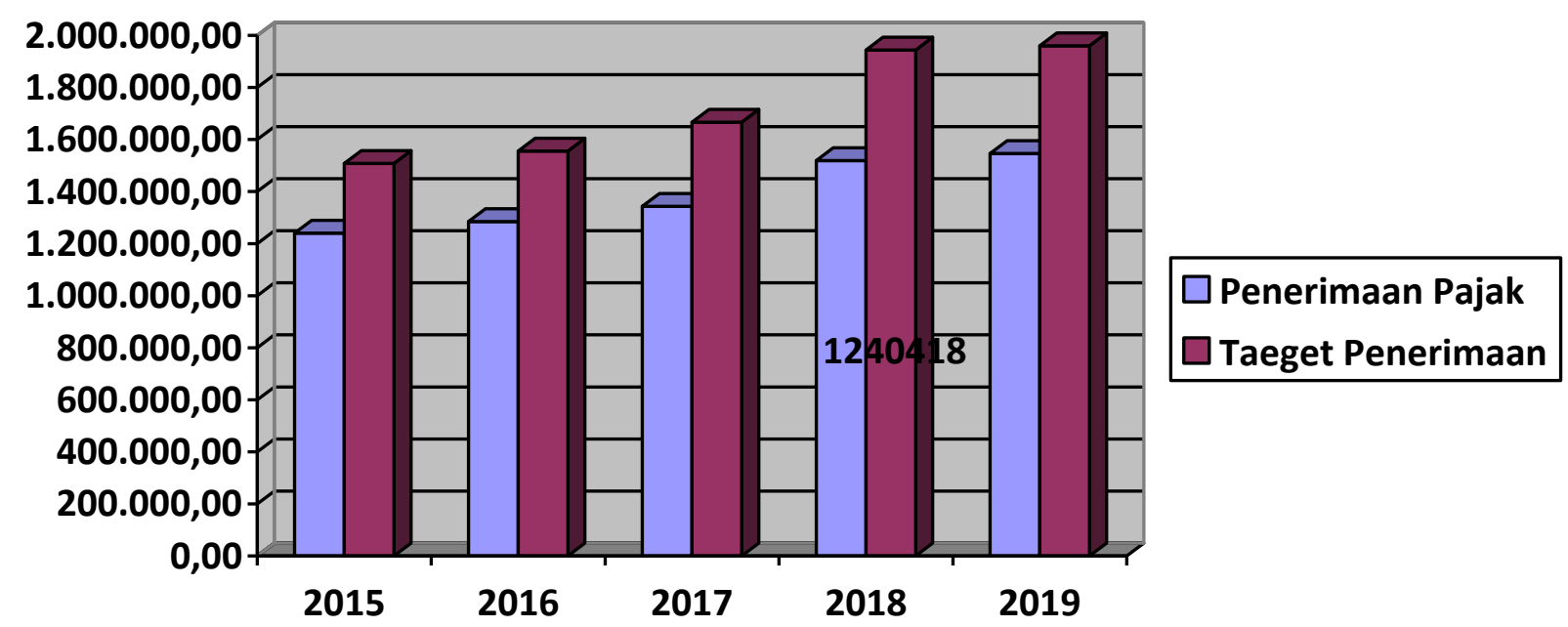

Sumber: $\underline{w w w . k e m e n k e u . g o . i d ~ d i o l a h ~(2021) ~}$

Catatan : Penerimaan pajak pada gambar kok tidak sesuai dengan tabel 1.

Sebagai contoh: Tahun $2017: 1.343 .529,80$; tapi pada gambar 1 berbeda.

Tahun 2019 keterangan tidak terlihat 
Dalam pelaksanaan penerimaan sektor pajak, salah satu pihak yang memberikan kontribusi besar yaitu perusahaan. Banyak perusahaan yang melakukan penghindaran pajak baik secara legal maupun secara ilegal, perusahaan akan berusaha mengelola beban pajaknya seminimum mungkin agar memperoleh laba yang maksimal (Dewinta dan Setiawan, 2016).

Perbedaan kepentingan antara pemerintah dan perusahaan. Menurut negara, pajak merupakan sumber pendapatan untuk mendanai penyelenggaraan pemerintah, bagi suatu perusahaan, pajak adalah biaya yang mengurangi laba perusahaan, karena semakin tinggi pajak yang ditanggung oleh suatu perusahaan berarti semakin kecil pula laba yang akan dihasilkan perusahaan tersebut. Perbedaan kepentingan ini membuat banyak perusahaan pada umumnya akan mengurangi jumlah pembayaran pajak, baik yang legal maupun yang ilegal, upaya untuk mengurangi pembayaran pajak yang legal disebut penghindaran pajak (tax avoidance), sedangkan upaya untuk mengurangi pembayaran pajak yang melanggar hukum disebut penggelapan pajak (tax evasion).

Yang dimaksud penghindaran pajak (tax avoidance) adalah sebagai penghematan pajak yang muncul dengan memanfaatkan ketentuan perpajakan yang dilakukan secara sah untuk meminimalkan kewajiban membayar pajak. Secara hukum penghindaran pajak tidak dilarang meskipun seringkali mendapat sorotan yang buruk dari kantor pajak karena dianggap memiliki makna yang negatif. Penghindaran pajak juga merupakan bagian dari tax planning yang dilakukan dengan tujuan meminimalkan pembayaran pajak (Dewinta dan Setiawan, 2016).

Menurut Prakoso (2018), ada tiga tahapan dilakukan perusahaan dalam meminimalkan pajak yaitu:

a. Perusahaan berusaha untuk menghindari pajak baik secara legal maupun ilegal.

b. Mengurangi beban pajak seminimal mungkin baik secara legal maupun ilegal.

c. Apabila kedua langkah sebelumnya tidak dapat dilakukan maka wajib pajak akan membayar pajak tersebut.

Salah satu fenomena yang terkait dengan penghindaran pajak di Indonesia adalah kasus penghindaran pajak yang dilakukan oleh Toyota Manufacturing Motor Indonesia (TMMIN) pada tahun 2013. Sengketa TMMIN terjadi sejak tahun 2008 lalu karena koreksi yang dilakukan oleh Ditjen Pajak terhadap nilai penjualan dan pembayaran royalti TMMIN yang diduga tidak wajar. Ditjen Pajak mengoreksi hitungan bisnis TMMIN setelah membandingkan bisnis TMMIN sebelum 2003 dengan sesudah 2003. Ditjen pajak melakukan koreksi terhadap laporan pajak yang TMMIN tahun 2008 yang menyatakan penjualan sebesar Rp. 32,9 triliun dan setelah dilakukan koreksi Ditjen Pajak menyatakan penjualan yang sebenarnya adalah sebesar Rp. 34,5 triliun. Dengan adanya penjualan yang disembunyikan sebesar Rp. 1,5 triliun pada akhirnya Ditjen Pajak mengharuskan TMMIN menambah pembayaran pajak sebesar Rp. 500 miliar kepada Negara (https://nasional.kontan.co.id).

Berdasarkan fenomena tersebut, hal ini membuktikan bahwa di Indonesia masih banyak perusahaan yang melakukan penghindaran pajak dan merupakan bukti bahwa penghindaran pajak harus mendapatkan perhatian lebih.

Beberapa penelitian sebelumnya telah menyatakan bahwa faktor kondisi keuangan perusahaan berpengaruh terhadap penghindaran pajak, ada beberapa faktor yang memengaruhi perusahaan untuk melakukan penghindaran pajak (tax avoidance) diantaranya, profitabilitas dan ukuran perusahaan. Profitabilitas merupakan salah satu pengukuran bagi kinerja perusahaan. Profitabilitas suatu perusahaan menggambarkan kemampuan suatu perusahaan dalam menghasilkan laba selama periode tertentu. Salah satu dari rasio 
profitabilitas adalah return on asset (ROA). Dalam penelitian ini rasio profitabilitas yang digunakan adalah ROA (Return on Asset) dimana ROA merupakan pengukuran kemampuan perusahaan secara keseluruhan di dalam menghasilkan keuntungan dengan jumlah keseluruhan aktiva yang tersedia di dalam perusahaan, semakin tinggi rasio ini berarti semakin baik keadaan suatu perusahaan. Return on assets (ROA) adalah rasio profitabilitas yang mengukur kemampuan perusahaan menghasilkan laba dari penggunaan seluruh sumber daya atau aset yang dimilikinya. Perusahaan yang memperoleh laba diasumsikan tidak melakukan penghindaran pajak karena mampu mengatur pendapatan dan pembayaran pajaknya. (Dewinta dan Setiawan, 2016).

Dalam penelitian terdahulu yang dilakukan Kurniasih dan Sari (2017) profitabilitas berpengaruh signifikan terhadap penghindaran pajak (tax avoidance). Sedangkan, dalam penelitian yang dilakukan oleh Ismiani Aulia (2020) bahwa profitabilitas tidak berpengaruh terhadap penghindaran pajak.

Faktor lain yang memengaruhi penghindaran pajak adalah ukuran perusahaan. Ukuran perusahaan menunjukkan kemampuan perusahaan untuk melakukan aktivitas ekonominya.

Menurut Merslythalia dan Lesmana (2016) menjelaskan bahwa:

"Semakin besar ukuran perusahaannya, maka transaksi yang dilakukan semakin kompleks, sehingga memungkinkan perusahaan untuk memanfaatkan celah-celah atau kelemahan yang ada pada ketentuan perundang-undangan untuk melakukan tindakan penghindaran pajak (tax avoidance) dari setiap transaksi".

Ukuran perusahaan dapat diklasifikasikan dengan cara antara lain: total aset dan penjualan bersih. Perusahaan yang mempunyai total asset yang besar sudah dikatakan dewasa dimana arus kas perusahaan sudah positif dan dianggap mempunyai prospek yang baik dalam jangka waktu panjang. Penelitian yang dilakukan oleh Kurniasih dan Sari (2013) menyatakan bahwa "Semakin besar perusahaan maka akan semakin rendah CETR yang dimilikinya". Hal ini dikarenakan perusahaan besar lebih mampu menggunakan sumber daya yang dimilikinya untuk membuat suatu perencanaan pajak yang baik. Namun perusahaan tidak selalu dapat menggunakan sumber daya yang dimilikinya untuk melakukan perencanaan pajak karena adanya batasan berupa kemungkinan menjadi sorotan dan sasaran dari keputusan regulator. Sehingga, akan menimbulkan kecenderungan manajer perusahaan untuk tidak melakukan penghindaran pajak.

Dalam penelitian terdahulu yang dilakukan oleh Kurniasih dan Sari (2017) menunjukkan adanya pengaruh negatif ukuran perusahaan terhadap penghindaran pajak, sedangkan menurut Merslythalia dan Lesmana (2016), ukuran perusahaan tidak berpengaruh terhadap penghindaran pajak.

\section{STUDI LITERATUR}

\section{Pengaruh Profitabilitas terhadap Penghindaran Pajak}

Tingkat profitabilitas diukur dengan menggunakan Return On Assets (ROA). ROA merupakan rasio yang menggambarkan kemampuan perusahaan dalam menghasilkan laba di perusahaan. Semakin tinggi nilai ROA perusahaan maka semakin berjalan dengan baik suatu perusahaan dalam menghasilkan laba. Hal tersebut sebagai indikator baik buruknya perusahaan dalam mengelola asetnya di dalam perusahaan untuk menghasilkan laba. Keterkaitan profitabilitas dengan pajak yaitu semakin tinggi kemampuan perusahaan dalam menghasilkan laba maka semakin tinggi pula pajak yang harus dibayarkan perusahaan kepada pemeritah. Perusahaan yang memiliki tingkat profitabilitas yang besar akan memiliki kemampuan untuk membayar pajak lebih tinggi daripada perusahaan yang memiliki tingkat profitabilitas yang kecil. Jika kemampuan perusahaan dalam menghasilkan laba meningkat, besarnya nilai pajak pada perusahaan tersebut juga akan 
meningkat, maka hal tersebut akan menimbulkan kecenderungan perusahaan melakukan penghindaran pajak yang dapat dilihat dari semakin kecilnya nilai Cash ETR. Dengan adanya hubungan profitabilitas terhadap penghindaran pajak maka hipotesis pada penelitian ini yaitu: (Dewinta dan Setiawan, 2016).

$\mathrm{H}_{1}$ : Profitabilitas berpengaruh terhadap penghindaran pajak.

\section{Pengaruh Ukuran Perusahaan terhadap Penghindaran Pajak}

Ukuran perusahaan dapat dilihat dari seberapa besar aset dari perusahaan tersebut. Maka dari hal tersebut, dapat dianggap ukuran perusahaan dapat memengaruhi tindak penghindaran pajak. Hal tersebut dikarenakan semakin besar aset yang dimiliki suatu perusahaan dapat meningkatkan kemungkinan perusahaan melakukan penghindaran pajak. Sebaliknya dengan ukuran perusahaan yang kecil kemungkinan perusahaan melakukan penghindaran pajak akan minimal karena aset yang dimilikinya sedikit. Besarnya ukuran perusahaan yang dilihat dari besarnya nilai aset perusahaan menunjukkan bahwa perusahaan tersebut akan lebih mampu dan lebih stail untuk menghasilkan laba. Dalam suatu perusahaan aset akan selalu mengalami penyusutan setiap tahunnya, hal tersebut dapat mengurangi laba perusahaan sehingga dapat menurunkan beban pajak yang dibayarkan oleh perusahaan. Dengan besarnya aset yang dimiliki perusahaan, perusahaan akan lebih mampu mengatur kekayaannya untuk melakukan perencanaan pajak yang lebih baik. berdasarkan uraian diatas maka hipotesis yang diajukan yaitu: Rinaldi dan Charoline (2015: 1)

$\mathrm{H}_{2}$ : Ukuran perusahaan berpengaruh terhadap penghindaran pajak.

\section{Pengaruh Profitabilitas dan Ukuran Perusahaan terhadap Penghindaran Pajak}

Profitabilitas dan ukuran perusahaan merupakan faktor yang dapat memengaruhi aktivitas penghindaran pajak dan memiliki pengaruh secara bersama-sama pada penghindaran pajak. Itu berarti jumlah keuntungan perusahaan dihasilkan melalui manajemen aset dan jumlah total aset yang dimiliki oleh perusahaan, dan kemudian akan mendorong perusahaan untuk melakukan perencanaan pajak dengan tindakan penghindaran pajak. Hal ini dibuktikan dalam penelitian yang dilakukan oleh Ida Ayu Rosa Dewinta \& Putu Ery Setiawan (2016) menyatakan bahwa ukuran perusahaan, umur perusahaan, profitabilitas, dan pertumbuhan penjualan berpengaruh positif terhadap tax avoidance.

$\mathrm{H}_{3}$ : Profitabilitas dan ukuran perusahaan berpengaruh terhadap penghindaran pajak.

\section{Pendekatan Penelitian}

\section{METODE}

Jenis penelitian yang digunakan yaitu deskripsi dengan metode analisis deskriptif kuantitatif. Penelitian ini menggunakan data sekunder yang diperoleh dari hasil dokumentasi. Analisis deskriptif kuantitatif dilakukan dengan cara mengumpulkan dan mengklasifikasikan menurut kriteria atau pola tertentu data- data yang telah dikuantifikasi dan analisis tersebut digunakan untuk mendapatkan gambaran sistematis mengenai isi dari suatu dokumen. (Sugiyino: 2017)

Sumber data yang digunakan dalam penelitian ini adalah sumber data sekunder, yaitu data yang diperoleh dari dokumen-dokumen yang sudah ada. Sehingga data dalam bentuk jadi, telah dikumpulkan lalu diolah oleh pihak lain dan biasanya dalam bentuk publikasi, Sugiyino: 2017. Data sekunder yang digunakan berupa laporan tahunan perusahaan (annual report) yang terdaftar di BEI pada tahun 2015-2019 yang berkaitan dengan variabel penelitian. Data dalam penelitian ini berasal dari website Bursa Efek Indonesia dan website perusahaan. 


\section{Populasi dan Sampel}

Menurut Sugiyono (2017:215) menjelaskan bahwa "Populasi adalah wilayah generalisasi yang terdiri atas: objek/subjek yang mempunyai kualitas dan karakteristik tertentu yang ditetapkan oleh peneliti untuk dipelajari dan kemudian ditarik kesimpulannya."

Dalam penelitian ini, yang menjadi populasi sebanyak 13 Perusahaan Sub Sektor Otomotif yang Terdaftar di Bursa Efek Indonesia.

Menurut Sugiyono (2017:81) menjelaskan bahwa:

"Sampel adalah bagian dari jumlah dan karakteristik yang dimiliki oleh populasi tersebut. bila populasi besar, dan peneliti tidak mungkin mempelajari semua yang ada pada populasi, misalnya karena keterbatasan dana, tenaga, dan waktu, maka peneliti dapat menggunakan sampel yang diambil dari populasi itu."

Dalam penelitian ini penulis menggunakan teknik sampling yaitu non probability sampling dengan pendekatan purposive sampling. Menurut Sugiyono (2017:82) menjelaskan bahwa non probability sampling "yaitu teknik pengambilan sampel yang tidak memberi peluang/kesempatan sama bagi setiap unsur atau anggota populasi untuk dipilih menjadi sampel." Selanjutnya menurut Sugiyono (2017:85) menjelaskan "purposive sampling yaitu teknik teknik penentuan sampel dengan pertimbangan tertentu".

Alasan pemilihan sampel dengan purposive sampling adalah karena tidak semua sampel memiliki kriteria yang sesuai dengan penelitian ini. Oleh karena itu hanya perusahaan-perusahaan tertentu yang memenuhi kriteria yang hanya dijadikan sampel. Pemilihan kriteria didasarkan pada indikator setiap variabel yang berkaitan. Adapun kriteria yang dijadikan sebagai sampel penelitian yaitu:

a. Perusahaan manufaktur sub sektor otomotif yang terdaftar di Bursa Efek Indonesia tahun 2015-2019.

b. Perusahaan yang memiliki laba yang positif selama periode penelitian tahun 20152019.

c. Laporan keuangan selama tahun 2015-2019 dapat diakses.

\section{Teknik Pengumpulan Data}

Menurut Sugiyono (2017:224) menjelaskan bahwa "Teknik Pengumpulan Data merupakan langkah yang paling strategis dalam penelitian, karena tujuan utama dari penelitian adalah mendapatkan data".

Teknik pengumpulan data yang digunakan dalam penelitian ini adalah dengan cara melakukan studi kepustakaan dan studi dokumentasi. Berikut ini akan dijelaskan teknik teknik pengumpulan data yang digunakan oleh peneliti sebagai berikut: Sugiyono (2017:224)

a. Studi Kepustakaan

Penelitian dilakukan dengan melihat sumber-sumber yang berasal dari literatur atau buku-buku yang berkaitan dengan objek penelitian sehingga dapat menunjang pengerjaan laporan tugas akhir.

b. Studi Dokumentasi

Pengumpulan data yang dilakukan dengan cara mempelajari atau mengumpulkan dokumen - dokumen yang dibuat oleh subjek sendiri atau oleh orang lain dari subjek dan pengumpulan data juga dilakukan dengan cara mengumpulkan seluruh data sekunder dari Bursa Efek Indonesia untuk mengetahui variabel yang akan diteliti. 


\section{Identifikasi dan Definisi Operasional Variabel Penelitian}

Definisi operasional variabel adalah objek atau kegiatan yang memiliki atribut, sifat, atau nilai dengan variasi tertentu yang telah dipilih oleh peneliti untuk diteliti dan diberikan kesimpulan (Sugiyono 2018:93). Variabel bebas (independent variable) yaitu variabel yang memengaruhi dan dapat memberi perubahan terhadap variabel terikat. Independent variable yang digunakan dalam penelitian ini adalah Profitabilitas dan Ukuran Perusahaan. Variabel terikat yaitu variabel yang dipengaruhi dan berubah. Variabel terikat yang dipakai dalam riset ini adalah Penghindaran Pajak. Indikator yang digunakan dalam setiap variabel yakni :

Tabel 1. Indikator variabel

\begin{tabular}{|c|c|c|c|}
\hline Variabel & Konsep Variabel & Indikator & Skala \\
\hline $\begin{array}{l}\text { Profitabilitas } \\
\left(\mathrm{X}_{1}\right)\end{array}$ & $\begin{array}{l}\text { Dalam penelitian ini rasio profitabilitas yang } \\
\text { digunakan yaitu ROA (Return on Asset) adalah } \\
\text { rasio keuntungan bersih pajak yang juga berarti } \\
\text { suatu ukuran untuk menilai seberapa besar } \\
\text { tingkat pengambilan dari aset yang dimiliki } \\
\text { perusahaan. ROA akan menunjukkan seberapa } \\
\text { efektif dan efisien perusahaan dalam mengelola } \\
\text { aktiva. Jadi semakin tinggi ROA, semakin tinggi } \\
\text { profitabilitas perusahaan. }\end{array}$ & $\begin{array}{l}\text { Return On Asset } \\
=\frac{\text { Laba Setelah Pajak }}{100 \%} \\
\quad \text { Total Aktiva }\end{array}$ & Rasio \\
\hline $\begin{array}{l}\text { Ukuran } \\
\text { Perusahaan } \\
\left(\mathrm{X}_{2}\right)\end{array}$ & $\begin{array}{l}\text { Ukuran perusahaan mengklasifikasikan } \\
\text { perusahaan berdasarkan skala besar kecilnya } \\
\text { perusahaan. Ukuran perusahaan dapat } \\
\text { diklasifikasikan menjadi empat, yaitu perusahaan } \\
\text { mikro, perusahaan kecil, perusahaan menengah, } \\
\text { dan perusahaan besar. Semakin besar ukuran } \\
\text { perusahaan akan dimiliki sumber daya yang } \\
\text { besar pula. }\end{array}$ & $\begin{array}{l}\text { Ukuran Perusahaan } \\
=\text { Ln Total Aset }\end{array}$ & Rasio \\
\hline $\begin{array}{l}\text { Penghindaran } \\
\text { Pajak (Y) }\end{array}$ & $\begin{array}{l}\text { Penghindaran pajak bukan merupakan suatu } \\
\text { pelanggaran baik terhadap undang-undang, } \\
\text { namun hal tersebut merupakan suatu usaha dari } \\
\text { wajib pajak untuk mengurangi, menghindari, } \\
\text { meminimalisir atau meringankan beban pajak } \\
\text { yang dilakukan dengan cara mencari celah atau } \\
\text { kekurangan dari undang-undang Nengsih, et al., } \\
\text { (2018: 3421). Penghindaran pajak akan diukur } \\
\text { dengan menggunakan proksi Cash Effective Tax } \\
\text { Rate, dikarenakan Cash ETR dapat menilai } \\
\text { pembayaran pajak dari laporan arus kas, } \\
\text { sehingga dapat mengetahui berapa jumlah kas } \\
\text { yang sesungguhnya dikeluarkan oleh } \\
\text { perusahaan. Semakin kecil nilai Cash ETR } \\
\text { menunjukkan bahwa semakin besar } \\
\text { penghindaran pajak yang dilakukan, begitupun } \\
\text { sebaliknya }\end{array}$ & $\begin{array}{l}\text { Cash Effective Tax Rate } \\
=\frac{\text { Pembayaran Pajak }}{\text { Laba Sebelum Pajak }}\end{array}$ & Rasio \\
\hline
\end{tabular}

Sumber: Data diolah (2021)

\section{Model Penelitian}

Menurut Siregar (2018:405) menjelaskan bahwa:

"Regresi linear berganda merupakan pengembangan dari regresi linear sederhana, yaitu sama-sama alat yang dapat digunakan untuk melakukan prediksi permintaan dimasa yang akan datang, berdasarkan data masa lalu untuk mengetahui pengaruh satu atau lebih 
variabel bebas (independent) terhadap satu variabel tak bebas (dependent)".

Persamaan regresi berganda dapat dirumuskan sebagai berikut:

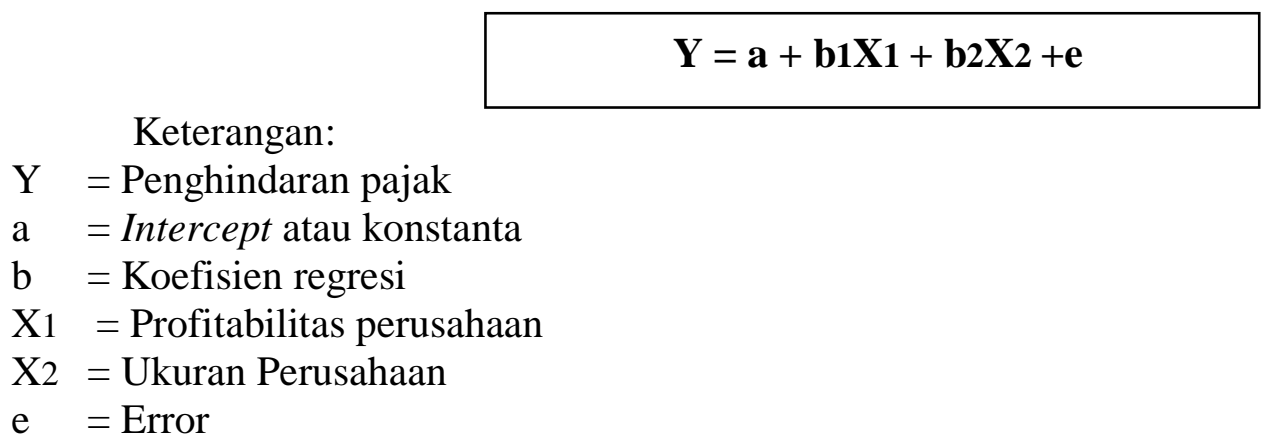

\section{Uji Asumsi Klasik Uji Normalitas}

Uji normalitas berfungsi untuk menguji apakah dalam sebuah model regresi, variabel pengganggu memiliki distribusi normal (Ghozali, 2018:160). Dalam penelitian ini akan digunakan uji One Sample Kolmogorov-Smirnov dengan menggunakan taraf signifikansi 0,05 . Data dinyatakan berdistribusi normal jika signifikansi lebih besar dari 0,05 .

\section{Uji Multikolinearitas}

Menurut Ghozali (2018: 105) uji multikolinearitas digunakan untuk mengetahui ada atau tidaknya korelasi antar variabel independen dalam model regresi. Model regresi yang baik adalah yang tidak mengandung multikolinearitas. Mendeteksi multikolinieritas dapat melihat nilai tolerance dan varian inflation factor (VIF) sebagai tolak ukur. Apabila nilai tolerance $\leq 0,10$ dan nilai VIF $\geq 10$ maka dapat disimpulkan bahwa dalam penelitian tersebut terdapat multikolinieritas (Ghozali,2018: 106).

\section{Uji Heteroskedastisitas}

Menurut Ghozali (2018:139) uji heteroskedastisitas digunakan untuk menguji apakah dalam sebuah regresi terjadi ketidaksamaan varian dari residual dari suatu pengamatan ke pengamatan lain. Prasyarat yang harus terpenuhi dalam model regresi adalah tidak adanya gejala heteroskedastisitas. Pada penelitian ini akan dilakukan uji heteroskedastisitas menggunakan uji glesjer yaitu mengkorelasikan nilai absolut residual dengan masing-masing variabel. Hasil dari uji glejser menunjukan tidak ada heteroskedastisitas apabila dari perhitungan SPSS nilai probabilitas signifikansinya diatas tingkat kepercayaan 5\% (Ghozali, 2018: 143).

\section{Uji Autokorelasi}

Menurut Imam Ghozali (2018: 110), uji autokolerasi bertujuan menguji apakah dalam model regresi linear ada kolerasi antara kesalahan pengganggu pada periode $t$ dengan kesalahan pengganggu pada periode t-1 (sebelumnya). Jika terjadi autokolerasi maka dinamakan ada problem autokolerasi. Pada penelitian ini, untuk mengetahui ada atau tidaknya autokorelasi digunakan uji Durbin Wastin (DW) dengan kriteria sebagai berikut:

1. $0<\mathrm{d}<\mathrm{dl}$, berarti tidak ada autokorelasi positif dan keputusannya ditolak.

2. $\mathrm{dl} \leq \mathrm{d} \leq \mathrm{du}$, berarti tidak ada autokorelasi positif dan keputusannya no desicison. 
3. $4-\mathrm{dl}<\mathrm{d}<4$, berarti tidak ada autokorelasi negatif dan keputusannya ditolak.

4. $4-\mathrm{du} \leq \mathrm{d} \leq 4-\mathrm{dl}$, berarti tidak ada autokorelasi negatif dan keputusannya no desicison.

5. du $<\mathrm{d}<4-\mathrm{du}$, berarti tidak ada autokorelasi positif atau negatif dan keputusannya tidak ditolak.

\section{Uji Hipotesis}

Dalam pengujian hipotesis peneliti menggunakan alat analisis berupa uji signifikan parsial (uji t), uji koefisien determinasi (R-squares), dan uji signifikan simultan (uji F).

\section{Uji Signifikan Parsial (Uji T)}

Menurut Siregar (2018:194) mengemukakan bahwa "Uji t digunakan untuk mengetahui kebenaran pernyataan atau dugaan yang dihipotesiskan oleh peneliti." Uji t disebut juga sebagai uji signifikan individual, dimana uji ini menentukan seberapa jauh pengaruh variabel independen secara parsial terhadap variabel dependen. Dalam penelitian ini memiliki tingkat signifikansi (t kritis) 0,05. Dasar untuk pengambilan keputusan dalam uji t ini adalah sebagai berikut:

1) Jika nilai signifikansi $>0,05$, maka Ho diterima dan Ha ditolak, artinya secara parsial variabel independen tidak berpengaruh terhadap variabel dependen.

2) Jika nilai signifikansi $\leq 0,05$, maka Ho ditolak dan Ha diterima, artinnya secara parsial variabel independen berpengaruh secara parsial terhadap variabel dependen.

Catatan : Tambahkan dulu uji asumsi klasik (Normalitas, Multikolinearitas, Heteroskedastisitas, dan Autokorelasi.

\section{Koefisien Determinasi (R-Squares)}

Menurut Widarjono (2015:17) koefisien determinasi $\left(\mathrm{R}^{2}\right)$ digunakan untuk mengukur seberapa baik kemampuan model regresi dalam menerangkan variasi variabel dependen $Y$ yang dijelaskan oleh variabel independen. Nilai koefisien determinasi terletak di antara 0 dan $1\left(0 \leq \mathrm{R}^{2} \leq 1\right)$. Semakin dekat nilai koefisien determinasi dengan angka 1, semakin baik pula model regresinya. Sebaliknya jika semakin dekat nilai koefisien determinasi dengan angka nol maka model regresinya kurang baik.

\section{Uji Signifikan Simultan (Uji F)}

Menurut Widarjono (2015:19) uji statistik $\mathrm{F}$ digunakan untuk mengevaluasi apakah semua variabel independen memiliki pengaruh secara bersama-sama terhadap variabel dependen. Uji statistik $\mathrm{F}$ ini dapat dijelaskan menggunakan analisis varian (ANOVA). Pengujian ini dilakukan dengan cara membandingkan $\mathrm{F}$ hitung dengan $\mathrm{F}$ tabel (F nilai kritis). Dasar untuk pengambilan keputusan dalam uji statistik F ini adalah sebagai berikut:

1) Jika nilai $\mathrm{F}$ hitung $\geq \mathrm{F}$ kritis, maka Ho ditolak, yang berarti secara bersama-sama terdapat pengaruh yang signifikan antara semua variabel independen terhadap variabel dependen.

2) Jika nilai $\mathrm{F}$ hitung $<\mathrm{F}$ kritis, maka Ho diterima, yang berarti secara bersama-sama tidak terdapat pengaruh yang signifikan antara semua variabel independen terhadap variabel dependen.

\section{Uji Regresi Linier Berganda}

\section{HASIL}

Uji regresi ini adalah memprediksikan nilai dari variabel dependen apabila nilai variable independen mengalami kenaikan atau penurunan dan untuk mengetahui arah 
hubungan antara variabel independen dengan variabel dependen apakah masing-masing variable independen berhubungan positif atau negatif. Berikut ini merupakan hasil pengolahan data dengan menggunakan bantuan program SPSS v25, hasil ini dapat dilihat pada tabel 2 sebagai berikut:

Tabel 2

Uji Regresi Linier Berganda

\begin{tabular}{|c|c|c|c|c|c|c|}
\hline \multirow[b]{3}{*}{ Model } & \multicolumn{6}{|c|}{ Coefficients $^{a}$} \\
\hline & \multicolumn{2}{|c|}{ Unstandardized Coefficients } & \multirow[b]{2}{*}{ Std. Error } & \multirow{2}{*}{$\begin{array}{l}\text { Standardized } \\
\text { Coefficients } \\
\text { Beta }\end{array}$} & \multirow[b]{2}{*}{$t$} & \multirow[b]{2}{*}{ Sig. } \\
\hline & & B & & & & \\
\hline 1 & (Constant) & 15,941 & 5,759 & & 2,768 & 011 \\
\hline & ROA &,- 471 & ,212 & - 321 & $-2,226$ & 037 \\
\hline & $\begin{array}{l}\text { UKURAN } \\
\text { PERUSAHAAN }\end{array}$ & 1,105 & ,261 & 609 & 4,231 &, 000 \\
\hline
\end{tabular}

a. Dependent Variable: PENGHINDARAN PAJAK

Sumber: Hasil olah SPSS 25

Berdasarkan tabel 2 dapat diketahui persamaan regresinya yaitu:

$$
\begin{aligned}
& \mathbf{Y}=\frac{\mathbf{Y}=\mathbf{a}+\mathbf{b} 1 \mathbf{X} 1+\mathbf{b} \mathbf{2} \mathbf{2} \mathbf{2}+\mathbf{e}}{15,941-0,471 \mathrm{X} 1+1,105 \mathbf{X} 2+\mathrm{e}} \\
& \text { Keterangan: } \\
& \mathrm{Y}=\text { Penghindaran pajak } \\
& \text { a } \quad=\text { Intercept } \text { atau konstanta } \\
& \mathrm{b} \quad=\text { Koefisien regresi } \\
& \mathrm{X} 1=\text { Profitabilitas perusahaan } \\
& \mathrm{X} 2=\text { Ukuran Perusahaan } \\
& \text { e }=\text { Error }
\end{aligned}
$$

Hasil analisis yang diperoleh sebagai berikut:

1) Nilai konstansta menunjukkan nilai sebesar 15,941 yang mengindikasikan bahwa jika variabel independen adalah 0 , maka variabel dependen akan mengalami kenaikan sebesar 15,941 .

2) Koefisien regresi variabel Profitabilitas (ROA) sebesar -0,471 menunjukkan arah negatif terhadap variabel Penghindaran Pajak. Tanda negatif pada koefisien menunjukkan bahwa peningkatan nilai variabel Profitabilitas (ROA) akan diikuti penurunan pada variabel Penghindaran Pajak. Jika variabel Profitabilitas (ROA) bertambah 1\%, maka Penghindaran Pajak akan menurun sebesar 0,471 satuan dengan asumsi variabel lain tetap atau tidak mengalami perubahan.

3) Koefisien regresi variabel Ukuran Perusahaan sebesar 1,105 menunjukkan arah positif terhadap variabel Penghindaran Pajak. Tanda positif pada koefisien menunjukkan bahwa peningkatan nilai Ukuran Perusahaan akan diikut peningkatan Penghindaran Pajak. Jika variabel Ukuran Perusahaan bertambah 1\%, maka Penghindaran Pajak akan meningkat 1,105.

\section{Uji Hipotesis}

Berdasarkan rumusan model regresi yang terbentuk, dilakukan uji hipotesis untuk mengukur ketepatan fungsi regresi dalam menaksir nilai aktual. Uji hipotesis ini 
meliputi uji t (parsial), koefisien determinasi (R-squares) dan uji F (simultan).

\section{Uji Signifikan Parsial (Uji t)}

Uji t (parsial) bertujuan untuk menunjukkan apakah dalam satu variabel independen secara individual memengaruhi variabel dependen. Jika hasil nilai signifikan lebih kecil dari 0,05 maka Ho ditolak atau dengan kata lain Ha diterima. Berikut ini merupakan hasil dari uji t yang dapat dilihat pada tabel 3 sebagai berikut:

\begin{tabular}{|c|c|c|c|c|c|c|}
\hline \multirow{3}{*}{\multicolumn{2}{|c|}{ Model }} & \multicolumn{3}{|c|}{$\begin{array}{c}\text { Uji t } \text { (Parsial) }_{\text {Coefficients }^{a}} \\
\end{array}$} & \multirow[b]{3}{*}{$t$} & \multirow[b]{3}{*}{ Sig. } \\
\hline & & \multicolumn{2}{|c|}{$\begin{array}{l}\text { Unstandardized } \\
\text { Coefficients }\end{array}$} & \multirow{2}{*}{$\begin{array}{l}\text { Standardized } \\
\text { Coefficients } \\
\text { Beta }\end{array}$} & & \\
\hline & & B & Std. Error & & & \\
\hline 1 & (Constant) & 15,941 & 5,759 & & 2,768 & ,011 \\
\hline & $\mathrm{ROA}$ &,- 471 & ,212 &,- 321 & $-2,226$ & 037 \\
\hline & $\begin{array}{l}\text { UKURAN } \\
\text { PERUSAHAAN }\end{array}$ & 1,105 & ,261 & ,609 & 4,231 &, 000 \\
\hline
\end{tabular}

Besarnya angka t tabel dengan ketentuan $\alpha=0,05 \mathrm{df}=(\mathrm{n}-\mathrm{k}-1)$ atau $(25-2-1)=22$ sehingga diperoleh nilai $t$ tabel sebesar 2,07387. berdasarkan tabel 3, maka dapat diketahui pengaruh masing-masing variabel sebagai berikut:

a) Variabel Profitabilitas (ROA) terhadap Penghindaran Pajak.

Dari tabel coefficients diperoleh nilai $\mathrm{t}$ hitung $=-2,226$ yang artinya $\mathrm{t}$ hitung $<\mathrm{t}$ tabel $(-2,226<-2,07387)$ dengan signifikansi $0,037<0,05$ maka Ho ditolak, dan Ha diterima artinya secara parsial Profitabilitas (ROA) berpengaruh negatif dan signifikan terhadap Penghindaran Pajak.

$\mathrm{H}_{1}$ : Profitabilitas berpengaruh terhadap penghindaran pajak.

\section{Diagram 2 Uji t}

Profitabilitas (ROA) terhadap Penghindaran Pajak

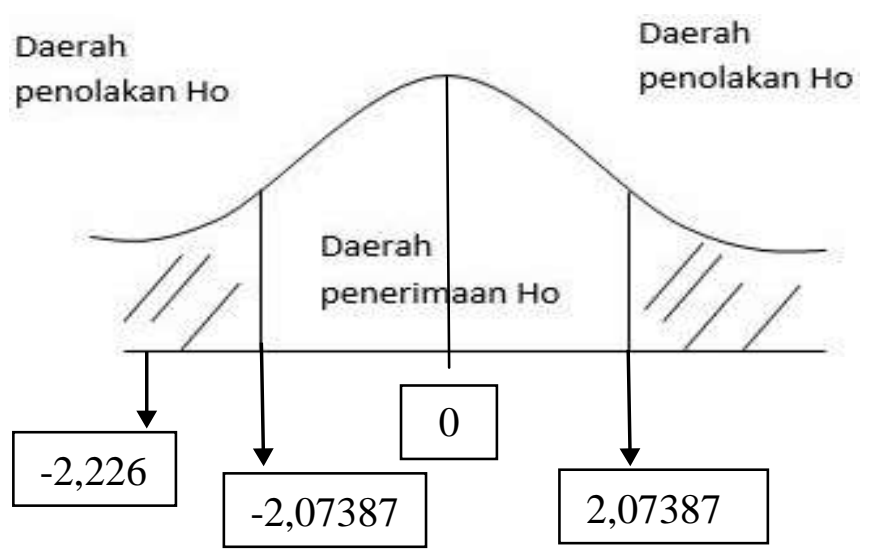

Sumber: Data diolah (2021) 
b) Variabel Ukuran Perusahaan terhadap Penghindaran Pajak.

Dari tabel coefficients diperoleh nilai $\mathrm{t}$ hitung $=4,231$ yang artinya $\mathrm{t}$ hitung $>\mathrm{t}$ tabel $(4,231>2.07387)$ dengan signifikansi $0,000<0,05$ maka Ho ditolak, dan Ha diterima. artinya secara parsial Ukuran Perusahaan berpengaruh positif dan signifikan terhadap Penghindaran Pajak.

$\mathrm{H}_{2}$ : Ukuran perusahaan berpengaruh terhadap penghindaran pajak.

\section{Diagram 3 Uji t \\ Ukuran Perusahaan terhadap Penghindaran Pajak}

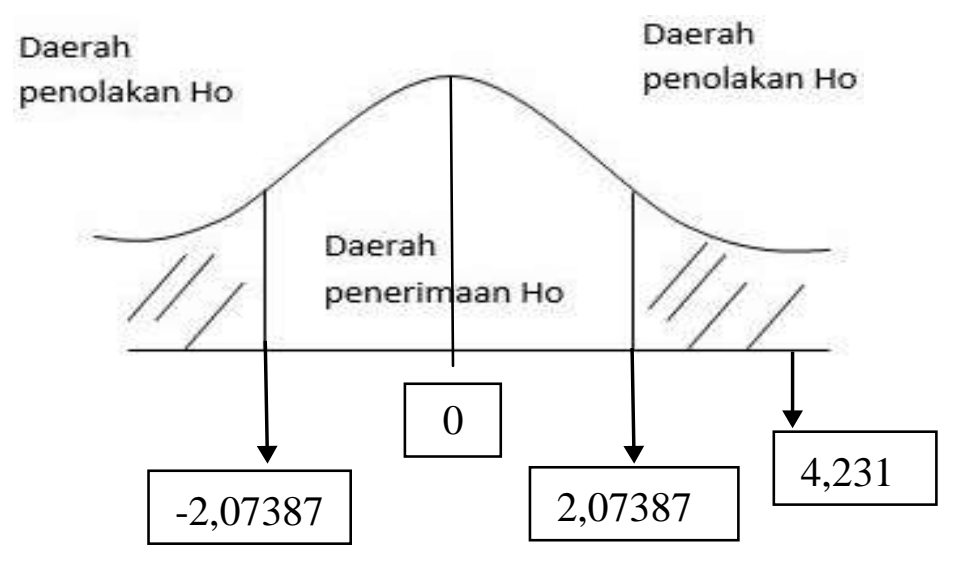

Sumber: Data diolah (2021)

\section{1) Koefisien Determinasi (R-Squares)}

Koefisien determinasi (R-Squares) digunakan untuk menguji seberapa besar peranan variabel independen untuk menjelaskan variabel dependen dalam model regresi. Hasil ini dapat dilihat pada tabel 4 sebagai berikut:

Tabel 4

\begin{tabular}{|c|c|c|c|c|c|}
\hline & \multicolumn{4}{|c|}{$\begin{array}{r}\text { Koefisien Determinasi ( } R \text {-Squares) } \\
\text { Model Summary }\end{array}$} & \\
\hline & $\mathrm{R}$ & & $\begin{array}{l}\text { Adjusted R } \\
\text { Square }\end{array}$ & $\begin{array}{l}\text { Std. Error of the } \\
\text { Estimate }\end{array}$ & \\
\hline 1 &, $757^{a}$ & ,573 & ,535 & 6,67359 & $\begin{array}{r}1,864 \\
\end{array}$ \\
\hline
\end{tabular}

Dari tabel 4 hasil uji koefisien determinasi diperoleh nilai $R$ Square sebesar 0,573. Hal tersebut berarti bahwa sebesar 57,3\% variabel dependen atau penghindaran pajak dipengaruhi oleh variabel independen yaitu profitabilitas dan ukuran perusahaan. Sedangkan untuk sisanya sebesar $100 \%-57,3 \%=42,7 \%$ dijelaskan oleh faktor-faktor lain yang tidak digunakan dalam penelitian ini.

\section{2) Uji Signifikan Simultan (Uji F)}

Uji F (simultan) dilakukan untuk mengevaluasi apakah semua variabel independen (Profitabilitas dan Ukuran Perusahaan) secara bersama-sama memiliki pengaruh secara bersama-sama terhadap variabel dependen. Uji $\mathrm{F}$ ini dijelaskan menggunakan analisis varian (ANOVA). Pengujian ini dilakukan dengan cara membandingkan $F$ hitung dengan $\mathrm{F}$ tabel ( $\mathrm{F}$ nilai kritis). Berikut ini merupakan hasil uji $\mathrm{F}$ yang dapat dilihat pada tabel 5 sebagai berikut: 


\begin{tabular}{|c|c|c|c|c|c|c|}
\hline \multirow[b]{2}{*}{ Model } & \multicolumn{6}{|c|}{$\begin{array}{c}\text { Tabel } 5 \\
\text { Uji F (Simultan) } \\
\text { ANOVA }^{\mathrm{a}}\end{array}$} \\
\hline & & Sum of Squares & $\mathrm{df}$ & Mean Square & $\mathrm{F}$ & Sig. \\
\hline \multirow[t]{3}{*}{1} & Regression & 1317,464 & 2 & 658,732 & 14,791 &, $000^{\mathrm{b}}$ \\
\hline & Residual & 979,809 & 22 & 44,537 & & \\
\hline & Total & 2297,273 & 24 & & & \\
\hline
\end{tabular}

b. Predictors: (Constant), UKURAN PERUSAHAAN, ROA

Sumber: Hasil olah SPSS 25

Besarnya angka $\mathrm{F}$ tabel dengan ketentuan $\alpha=0,05 \mathrm{df}=(\mathrm{n}-\mathrm{k}-1)$ atau $(25-2-1)=22$ sehingga diperoleh nilai $\mathrm{F}$ tabel sebesar 3,44. Berdasarkan hasil uji simultan didapatkan $\mathrm{F}$ hitung sebesar 14,791. Karena F hitung > F tabel $(14,791>3,44)$ maka dapat dinyatakan bahwa variabel independen yang meliputi Profitabilitas (ROA) dan Ukuran Perusahaan secara simultan atau bersama-sama memengaruhi variabel dependen yaitu Penghindaran Pajak.

\section{PEMBAHASAN}

Penelitian ini bertujuan untuk mengetahui pengaruh profitabilitas dan ukuran perusahaan terhadap penghindaran pajak pada perusahaan manufaktur sub sektor otomotif periode 2015-2019. Pembahasan mengenai hal-hal sebagai berikut:

\section{Hubungan Profitabilitas (ROA) terhadap Penghindaran Pajak}

Hasil penelitian menunjukan bahwa secara parsial Profitabilitas (ROA) berpengaruh negatif dan signifikan terhadap Penghindaran Pajak pada perusahaan manufaktur sub sektor otomotif periode 2015-2019, yang didapat dari hasil uji t dengan nilai signifikan lebih kecil dari 0,05. artinya secara parsial Profitabilitas berpengaruh negatif dan signifikan terhadap Penghindaran Pajak. Semakin tinggi profitabilitas perusahaan maka semakin rendah tax avoidance. Semakin besar laba maka profitabilitas perusahaan juga akan meningkat, namun hal ini justru mengakibatkan jumlah pajak yang harus dibayar oleh perusahaan juga tinggi. Hasil penelitian ini sejalan dengan penelitian yang dilakukan oleh Tresna Syah Rozak (2018) dan Cici Dwi Anggriantari yang menunjukkan bahwa profitabilitas berpengaruh negatif dan signifikan terhadap penghindaran pajak. Namun penelitian ini tidak sejalan dengan penelitian yang dilakukan oleh Maharani dan Suardana (2014) dan Aulia (2020) yang menunjukkan bahwa profitabilitas tidak berpengaruh terhadap penghindaran pajak.

\section{Hubungan Ukuran Perusahaan terhadap Penghindaran Pajak}

Hasil penelitian menunjukan bahwa secara parsial Ukuran Perusahaan berpengaruh positif dan signifikan terhadap Penghindaran Pajak pada perusahaan manufaktur sub sektor otomotif periode 2015-2019, yang didapat dari hasil uji t dengan nilai signifikan lebih kecil dari 0,05. artinya secara parsial Ukuran Perusahaan berpengaruh positif dan signifikan terhadap Penghindaran Pajak. Dengan hasil penelitian yang memberikan hasil bahwa ukuran perusahaan berpengaruh terhadap penghindaran pajak, berarti bahwa dengan semakin besarnya ukuran perusahaan, semakin besar pula kemampuan perusahaan untuk melakukan perencanaan pajak dengan lebih baik. Hasil penelitian ini sejalan dengan penelitian yang dilakukan oleh Ardiansyah (2014) dan Ridho (2016) yang menunjukkan bahwa ukuran perusahaan berpengaruh dan signifikan terhadap penghindaran pajak. Namun penelitian ini tidak sejalan dengan penelitian yang dilakukan 
oleh Utami (2013) yang menunjukkan bahwa ukuran perusahaan tidak berpengaruh terhadap penghindaran pajak.

\section{Hubungan profitabilitas dan ukuarn perusahaan terhadap penghindaran pajak}

Hasil penelitian menunjukkan bahwa terdapat pengaruh yang signifikan secara simultan antara profitabilitas dan ukuarn perusahaan terhadap penghindaran pajak pada perusahaan manufaktur sub sektor otomotif periode 2015-2019, yang didapat dari hasil uji F yang menunjukkan hasil positif, maka dapat dinyatakan bahwa variabel independen yang meliputi Profitabilitas (ROA) dan Ukuran Perusahaan secara simultan atau bersamasama mempengaruhi variabel dependen yaitu Penghindaran Pajak.

\section{KESIMPULAN}

1. Terdapat pengaruh negatif dan signifikan secara parsial antara variabel profitabilitas (ROA) terhadap penghindaran pajak pada perusahaan manufaktur sub sektor otomotif,

2. Terdapat pengaruh positif dan signifikan secara parsial antara variabel ukuran perusahaan terhadap penghindaran pajak pada perusahaan manufaktur sub sektor otomotif.

3. Terdapat pengaruh yang signifikan secara simultan antara profitabilitas (ROA) dan ukuran perusahaan terhadap penghindaran pajak pada perusahaan manufaktur sub sektor otomotif.

\section{REFERENSI}

Agusti, W. Y. (2014). Pengaruh Profitabilitas, Leverage, Corporate Governance Terhadap Tax Avoidance. Universitas Negeri Padang.

Ahmadi. Edy Anas, Herwidyaningtyas, Fristina Bhakti, Fatimah. Siti. 2020. The Influence Of Organizational Culture, Work Motivation, And Job Satisfaction On Management Lecturer Performance (Empirical Study At Higher Education In The Residency Of Bojonegoro. Journal Of Industrial Engineering \& Management Research. Jilid 1. Terbitan 3 Halaman 76-83

Ahmadi. Edy Anas. 2020. Analisis Trend Penerimaan Dan Efektivitas Pajak Hotel Dan Pajak Restoran Di Kabupaten Bojonegoro Tahun 2016-2020 (Studi Kasus Pada Dinas Pendapatan Daerah Kabupaten Bojonegoro). Sultanist: Jurnal Manajemen Dan Keuangan. Jilid 8. Terbitan 2. Halaman 182-192

Astutik, R. E. (2016). Pengaruh Perencanaan Pajak Dan Beban Pajak Tangguhan Terhadap Manajemen Laba. Jurnal Ilmu dan Riset Akuntansi : Volume 5, Nomor 3, Maret 2016.

Aulia, Ismiani (2020). Pengaruh Profitabilitas, Leverage dan Ukuran Perusahaan terhadap Tax Avoidance. Universitas Singaperbangsa Karawang.

Chen et al., (2010). Are Family Firms More Tax Aggressive Than Non-Family Firms?Journal of Financial Economics, 41-61.

Dendawijaya, L. (2009), Manajemen Perbankan, Penerbit Ghalia Indonesia.

Dewi, Ni Luh Putu Puspita. Naniek Noviari. (2017). Pengaruh ukuran perusahaan, leverage, profitabilitas, dan corporate social responsibility terhadap penghindaran pajak (tax avoidance). EJurnal Akuntansi Universitas Udayana Vol.21.1 : 830-859.

Dewinta, Ida Ayu Rosa. Putu Ery Setiawan. (2016), Pengaruh ukuran perusahaan, umur perusahaan, profitabilitas, leverage, dan pertumbuhan penjualan tehadap tax avoidance. ISSN: 2302-8556 E-Jurnal Akuntansi Universitas Udayana 
Vol.14.3.1584-1613.

Ghozali, I. (2018). Aplikasi Analisis Multivariate dengan Program IBM SPSS 25.

Semarang: Badan Penerbit Universitas Diponegoro.

Hery. (2016). Analisis Laporan Keuangan. Jakarta: Grasindo.

Hartono, J. (2015). Teori Portofolio dan Analisis Investasi. Edisi 5. Jakarta: Rajawali Pers.

Handayani, R. (2018). Pengaruh Return On Assets (Roa), Leverage Dan Ukuran

Perusahaan Terhadap Tax Avoidance Pada Perusahaan Perbankan Yang Listing Di

Bei Periode Tahun 2012-2015. Jurnal Akuntansi Maranatha, 10(1), 72-84.

Kurniasih, T., \& Sari, M. M. (2013). Pengaruh Return On Assets, Leverage, Corporate Governance, Ukuran Perusahaan Dan Kompensasi Rugi Fiskal Pada Tax Avoidance. Buletin Studi Ekonomi, 18, 58 - 66.

Kasmir. (2017). Analisis Laporan Keuangan. Jakarta: Raja Grafindo Persada.

Merslythalia, R., \& Lasmana, M. S. (2016). Pengaruh Kompetensi Eksekutif, Ukuran Perusahaan, Komisari Independen dan Kepemilikan Institusional.

Mahpudin, E. (2016). Faktor-faktor yang Mempengaruhi Nilai Perusahaan (Studi Empiris pada Perusahaan Manufaktur yang Terdaftar di Bursa Efek Indonesia). JRKA. Volume 2. Isue 2.

Mardiasmo. (2016). Perpajakan Edisi Revisi Tahun 2016. Yogyakarta: Penerbit Andi.

Merslythalia, R., \& Lasmana, M. S. (2016). Pengaruh Kompetensi Eksekutif, Ukuran Perusahaan, Komisari Independen dan Kepemilikan Institusional.

Nugrahitha, I. M., \& Suprasto, H. B. (2018). Pengaruh profitabilitas ,Leverage, Corporate Governance, dan karakter Eksekutif pada Tax Avoidance. E- jurnal akuntansi universitas udayana. Vol. 22 Nomor 3. Hal 2016-2039.

Ngadiman, \& Puspitasari, C. (2014). Pengaruh Kepemilikan Institusional, Dan Ukuran Perusahaan Terhadap Penghindaran Pajak. Jurnal Akuntansi Xviii(3):408-421.

Nur, I. I. (2010). Implementasi Manajemen Pajak Pada PT. Mega Visual Elektronik dan Dampaknya Terhadap Laporan Keuangan. Banten: Universitas Multimedia .

Prakoso, K. B. (2014). Pengaruh Profitabilitas, Kepemilikan Keluarga dan Corporate Governance Terhadap Penghindaran Pajak di Indonesia. SNA 17 Mataram.

Pohan, C. A. (2013). Manajemen Perpajakan: Strategi Perencanaan Pajak dan Bisnis. Jakarta: PT Gramedia Pustaka Utama.

Priyatno, Duwi. Cara Kilat Belajar Analisis Data dengan SPSS 20. Yogyakarta: ANDI, 2012

Rusman, Tedi. 2015. Statistika Penelitian; Aplikasinya dengan SPSS. Yogyakarta: Graha Ilmu

Ridho, M. (2016). Pengaruh Ukuran Perusahaan, Leverage, Profitabilitas dan Sales Growth terhadap Praktik Penghindaran Pajak (Tax Avoidance) pada Perusahaan Manufaktur di Bursa Efek Indonesia (BEI) Tahun 2010- 2014. Skripsi. Universitas Islam Negeri Syarif Hidayatullah.

Resmi, Siti. 2017. Perpajakan Teori dan Kasus (Edisi ke 10 Buku 1). Jakarta: Salemba Empat.

Suandy, E. (2016). Perencanaan Pajak. Jakarta: Salemba Empat.

Sugiyono. (2017). Metode Penelitian Kuantitatif, Kualitatif, dan R\&D. Bandung: Alfabeta, CV.

Santoso, S. (2019). Statistik Parametrik: Konsep dan Aplikasi dengan SPSS. Jakarta: PT Elex Media Komputindo

Siregar, Syofian. (2018). Statistika Parametrik untuk Penelitian Kuantitatif. Jakarta: Bumi Aksara. 
Sirait, P. (2017). Analisis Laporan Keuangan. Yogyakarta: Ekuilibria.

Undang Undang Nomor 16 tahun 2009. Tentang Ketentuan Umum dan Tata Cara Perpajakan.

Undang-Undang Republik Indonesia No. 20 Tahun 2008. Tentang Usaha Mikro, Kecil, dan Menengah.

Widarjono. (2018). Analisis Multivariat Terapan: Dengan program SPSS, AMOS, dan SMARTPLS. Yogyakarta: UPP STIM YKPN.

www.idx.co.id diakses 2021

www.bps.go.id diakses 2021

www.kemenkeu.go.id diakses 2021

https://nasional.kontan.co.id/news/sengketa-pajak-toyota-motor-menanti-paluhakim. diakses 2021 